\begin{abstract}
"Mircea cel Batran" Naval Academy Scientific Bulletin, Volume XIX - 2016 - Issue 1
Published by "Mircea cel Batran" Naval Academy Press, Constanta, Romania /I The journal is indexed in:

PROQUEST / DOAJ / DRJI / JOURNAL INDEX / I2OR / SCIENCE LIBRARY INDEX / Google Scholar / Crossref /

Academic Keys I ROAD Open Access / OAJI / Academic Resources / Scientific Indexing Services / SCIPIO
\end{abstract}

\title{
COMMUNICATION PROBLEMS IN A MIXED CREW ENVIRONMENT
}

\author{
Carmen ASTRATINEI ${ }^{1}$ \\ ${ }^{1}$ Assoc. Prof. PhD, Navigation and Naval Transport , „Mircea cel Batran” Naval Academy
}

\begin{abstract}
Shipping has become a highly international and multicultural industry due to a globalised labour market of seafarers. About two thirds of the world's merchant fleets, are manned by a mixed crew, which may include two to three different nationalities. The common language used on board ship is English. So the crewmembers must have a good command of this language. $80 \%$ of all maritime accidents are, according to incident reports, caused by human error i.e. negligence, fatigue, incompetence or communication breakdown. Another factor that may affect the safety of crew and cargo is the cultural differences within the mixed nationality crews which, if not appeased in time, may lead to very serious conflicts. This paper proposes to analyse some characteristics of the Asian culture and traditions and suggest some ways of improving the professional relationship among multinational crew members by making them aware of their shipmates identities. A questionnaire, which we intend to use as a research tool, will be provided and explained.
\end{abstract}

\section{Key words: mixed nationality crews cultural differences human element communication}

\section{Introduction}

The increase in technology, the reduction in manning scales, the employment aboard ships of multi-national crews due to economic reasons (i.e. fewer employees and cheaper manpower mean important cutting down costs for shipping companies). The employment of multicultural crews has given rise to such issues as communication problems which may affect the safety of the crew and cargo. Communication is an essential part of human interaction. In seafarer profession misunderstandings may lead to serious maritime incidents involving the safety of the crew and cargo as well as the protection of the environment. So the issue is that on board a mixed nationality crew, where the official language for alarms and orders is English, measures should be taken (both by the shipping companies and by the Master) that the crew members can account for their competency in Maritime English, in compliance with the STCW'98 requirements and that the crew members nationalities are compatible in the sense that they can work together as a team. In order that this compatibility should be achieved, training courses in other cultures traditions and ways of behaviour should be organised both for the managers and for the crews.

\section{The Asian Culture}

We have chosen the Asian Culture because most of the multinational crewmembers are Asians and the shipping companies and ship masters should have an insight into this culture so as to be able to train their other nationality employees to know what to do or not to do to avoid offending their Asian mates in any way, thus ensuring an amiable

DOI: 10.21279/1454-864X-16-I1-002

(c) 2015. This work is licensed under the Creative Commons Attribution-Noncommercial-Share Alike 4.0 License. work environment. The idea goes both ways. The Asian crew members should be trained in their other nationality colleagues`culture and traditions as well.

Here are some do`s and don'ts when you have Asian colleagues. It is a synthesis of the Globe Study of 62 Societies, Stage Publication 2004, findings about Korean, Indian, Japanese and Chinese cultures. Common behavioural features for Asian people would be honesty, modesty, punctuality, patience, loyalty, respect for the family concept and for religious and cultural beliefs, for relationship and trust in other people. So in order to avoid conflicts, people of other nationalities should not be too direct in their conversation with their Asian mates, should not be in any way aggressive either physically or verbally, nor should show anger. The Asians are obedient and know very well how to carry out precise orders. They do not have to be shouted at because this means aggression which discourages and prevents them from carrying out their duties properly.

Our point is that multicultural crews should attend some courses on intercultural awareness so as to be familiarised with other cultures ways and traditions. Therefore, a coursebook should be designed in this respect. In order to design a coursebook you have to do some inquiry, some quantitative and qualitative research to collect information about the problems occurring in multinational crews and then decide on the solutions to avoid them.

So we have designed a questionnaire to be addressed to seafarers of all nationalities to state 
"Mircea cel Batran" Naval Academy Scientific Bulletin, Volume XIX - 2016 - Issue 1

Published by "Mircea cel Batran" Naval Academy Press, Constanta, Romania /I The journal is indexed in:

PROQUEST / DOAJ / DRJI / JOURNAL INDEX / I2OR / SCIENCE LIBRARY INDEX / Google Scholar / Crossref /

Academic Keys / ROAD Open Access / OAJI / Academic Resources / Scientific Indexing Services / SCIPIO

their opinion mainly on the advantages and disadvantages of working in a mixed crew environment. After analysing the answers and comments, there will be an interview with volunteers who will state their opinions on what it means for them working with foreign mates. The course will be designed based on all the findings provided by the survey.

The questionnaire is meant to reveal some essential aspects of the mixed nationality crew cohabitation on board ship, which is a confined space where you meet the same people every day for months. It has two parts. Part A refers to manning i.e. number of crew complement and

\section{QUESTIONNAIRE}

\section{PART A}

NAME:

SURNAME:

RANK:

NATIONALITY:

NAME OF VESSEL AND CALL SIGN:

TYPE OF VESSEL:

NUMBER OF CREW COMPLEMENT:

-MASTER-NATIONALITY:

-CHIEF MATE-NATIONALITY:

-SECOND OFFICER-NATIONALITY:

-THIRD OFFICER-NATIONALITY:

-DECK CADET-NATIONALITY:

- AB-NATIONALITY:

-OS-NATIONALITY:

-CHIEF ENGINEER-NATIONALITY:

-ELECTRICAL OFFICER (IF ANY)-NATIONALITY: -FITTERS-NATIONALITY:

DURING YOUR LAST VOYAGE, HAVE YOU WITNESSED ANY ANIMOSITIES OR CONFLICTS AMONG CREW MEMBERS OF DIFFERENT NATIONALITIES?

If YES, please comment on the incidents from your perspective

PLEASE COMMENT ON YOUR RELATION WITH YOUR SHIPMATES OF DIFFERENT NATIONALITIES, ie. socializing, having affinities with some nationalities, feeling uneasy in the company of other ones, etc. ranks, and questions eliciting the respondents commentaries on crises situations meaning conflicts between crew members of different nationalities, work and free time relationship among shipmates, opinion on the advantages and disadvantages of working in a multicultural environment. Part B requires respondents to tick the most suitable description of the situation. This part refers to crew members' attitude towards superiors, response to emergency situations, and again comments on the causes of communication problems on board ship and solutions for reducing maritime incidents caused by communication breakdown and ethnic incompatibilities.

\section{.................... \\ PLEASE STATE THREE ADVANTAGES AND THREE DISADVANTAGES OF WORKING IN A MULTINATIONAL CREW.}


"Mircea cel Batran" Naval Academy Scientific Bulletin, Volume XIX - 2016 - Issue 1

Published by "Mircea cel Batran" Naval Academy Press, Constanta, Romania /I The journal is indexed in:

PROQUEST / DOAJ / DRJI / JOURNAL INDEX / I2OR / SCIENCE LIBRARY INDEX / Google Scholar / Crossref /

Academic Keys / ROAD Open Access / OAJI / Academic Resources / Scientific Indexing Services / SCIPIO

\section{PART B}

Attitude of your multinational co-workers towards superiors:

$\begin{array}{llll}\begin{array}{l}\text { Filipinos: } \\ \text { Obedient } \mathrm{O}\end{array} & \text { Reluctant } \mathrm{O} & \text { Aggressive } \mathrm{O} & \text { Normal O } \\ \begin{array}{l}\text { Slavs: } \\ \text { Obedient } \mathrm{O}\end{array} & \text { Reluctant } \mathrm{O} & \text { Aggressive } \mathrm{O} & \text { Normal O } \\ \begin{array}{l}\text { Greeks: } \\ \text { Obedient O }\end{array} & \text { Reluctant } \mathrm{O} & \text { Aggressive } \mathrm{O} & \text { Normal O } \\ \begin{array}{l}\text { Westerners: } \\ \text { Obedient O }\end{array} & \text { Reluctant } \mathrm{O} & \text { Aggressive } \mathrm{O} & \text { Normal O } \\ \begin{array}{l}\text { Romanians: } \\ \text { Obedient O }\end{array} & \text { Reluctant } \mathrm{O} & \text { Aggressive O } & \text { Normal O } \\ \begin{array}{l}\text { Arabs: } \\ \text { Obedient O } \\ \text { Indians: } \\ \text { Obedient O }\end{array} & \text { Reluctant O } & \text { Aggressive O } & \text { Normal O } \\ \end{array}$

Multinational crew members' response to emergency situations:

Filipinos:

\begin{tabular}{|c|c|c|c|}
\hline $\begin{array}{l}\text { Self-confident O } \\
\text { Slavs: }\end{array}$ & Panic-stricken $\mathrm{O}$ & Balanced $\mathrm{O}$ & Efficient $\mathrm{O}$ \\
\hline $\begin{array}{l}\text { Self-confident O } \\
\text { Greeks: }\end{array}$ & Panic-stricken $\mathrm{O}$ & Balanced $\mathrm{O}$ & Efficient $\mathrm{O}$ \\
\hline $\begin{array}{l}\text { Self-confident O } \\
\text { Westerners: }\end{array}$ & Panic-stricken $\mathrm{O}$ & Balanced $\mathrm{O}$ & Efficient $\mathrm{O}$ \\
\hline $\begin{array}{l}\text { Self-confident O } \\
\text { Romanians: }\end{array}$ & Panic-stricken $\mathrm{O}$ & Balanced $\mathrm{O}$ & Efficient $\mathrm{C}$ \\
\hline $\begin{array}{l}\text { Self-confident } O \\
\text { Arabs: }\end{array}$ & Panic-stricken $\mathrm{O}$ & Balanced $\mathrm{O}$ & Efficient \\
\hline $\begin{array}{l}\text { Self-confident O } \\
\text { Indians: }\end{array}$ & Panic-stricken $\mathrm{O}$ & Balanced $\mathrm{O}$ & Efficient $\mathrm{C}$ \\
\hline Self-confident O & $\begin{array}{l}\text { Panic-stricken } \mathrm{O} \\
\text { ation problems }\end{array}$ & Balanced O & Efficient \\
\hline Cultural $\mathrm{O}$ & Competence in & English $\mathrm{O}$ & Others $\mathrm{O}$ \\
\hline
\end{tabular}

Could you provide any solutions for reducing maritime incidents caused by communication breakdown and ethnic incompatibilities?

Thank you for participating in the survey

\section{CONCLUSIONS}

The conclusion is that in order to ensure the safety of crew and cargo on board ships, the crewing agencies recruitment procedures should include in the first place a very relevant test in Maritime English knowledge for the on board and external communications and give the proper recommendations for improvement in case the recruited candidate fails the test.

In the second place, the training in cultural awareness rests with the shipping companies, the masters and MET institutions. We still believe that nationality compatibility is very important for avoiding ethnical conflicts or animosities on board ship. On the other hand, we assume that the shipping companies are constrained by the market demand and offer, so they will accept the lowest price bidder in order to make a profit. So it hard to believe that they will afford to think of the right ethnical combination. 
"Mircea cel Batran" Naval Academy Scientific Bulletin, Volume XIX - 2016 - Issue 1

Published by "Mircea cel Batran" Naval Academy Press, Constanta, Romania /I The journal is indexed in:

PROQUEST / DOAJ / DRJI / JOURNAL INDEX / I2OR / SCIENCE LIBRARY INDEX / Google Scholar / Crossref /

Academic Keys I ROAD Open Access / OAJI / Academic Resources / Scientific Indexing Services / SCIPIO

The final idea is that all the parties involved in the shipping industry i.e. IMO, shipping companies, crewing agencies and MET institutions, should concentrate their forces and find a common solution for ensuring the safety of the crew and cargo and reducing the number of maritime incidents caused by communication breakdowns to a minimum.

\section{BIBLIOGRAPHY}

[1] House RJ et al. culture, leadership, and organization: the GLOBE Study of 62 Societies, Sage Publications 2004

[2] http://textbook.ncmm.no/component/content/article/39-6-the-sea-as-a-working-place/760-multinationalcrews-a-communication

[3] The Importance of effective communication, Commodore David Squire, CBE, FNI, Editor, Alert-The International Maritime Human Element Bulletin 